\title{
Persistent Representation of Juvenile Experience in the Adult Songbird Brain
}

\author{
Jonathan F. Prather, ${ }^{1}$ Susan Peters, ${ }^{2}$ Stephen Nowicki, ${ }^{1,2}$ and Richard Mooney ${ }^{1}$ \\ ${ }^{1}$ Department of Neurobiology, Duke University Medical Center, and ${ }^{2}$ Department of Biology, Duke University, Durham, North Carolina 27710
}

Juveniles sometimes learn behaviors that they cease to express as adults. Whether the adult brain retains a record of experiences associated with behaviors performed transiently during development remains unclear. We addressed this issue by studying neural representations of song in swamp sparrows, a species in which juveniles learn and practice many more songs than they retain in their adult vocal repertoire. We exposed juvenile swamp sparrows to a suite of tutor songs and confirmed that, although many tutor songs were imitated during development, not all copied songs were retained into adulthood. We then recorded extracellularly in the sensorimotor nucleus HVC in anesthetized sparrows to assess neuronal responsiveness to songs in the adult repertoire, tutor songs, and novel songs. Individual HVC neurons almost always responded to songs in the adult repertoire and commonly responded even more strongly to a tutor song. Effective tutor songs were not simply those that were acoustically similar to songs in the adult repertoire. Moreover, the strength of tutor song responses was unrelated to the number of times that the bird sang copies of those songs in juvenile or adult life. Notably, several neurons responded most strongly to a tutor song performed only rarely and transiently during juvenile life, or even to a tutor song for which we could find no evidence of ever having been copied. Thus, HVC neurons representing songs in the adult repertoire also appear to retain a lasting record of certain tutor songs, including those imitated only transiently.

\section{Introduction}

Adult behaviors are often learned during a juvenile sensitive period, indicating the brain contains a lasting record of early experience (Knudsen, 2004). Sometimes, however, a juvenile learns more behaviors than are retained in its adult repertoire (Marler, 1991; Locke, 1993). Although such "exuberant" juvenile learning can influence adult performance on perceptual tasks (Tees and Werker, 1984; Geberzahn et al., 2002), the discrete neuronal representation of such lasting experience is poorly understood. Conversely, although the lasting neuronal effects of sensory deprivation and other forms of aberrant early experience are well documented (Hubel and Wiesel, 1965; Fox, 1992; Knudsen, 1998), whether these persistent effects resemble the lasting effects of experience associated with natural forms of exuberant learning is uncertain. Resolving how the adult brain encodes experience associated with behaviors performed only transiently during development can benefit from studying animals that display exuberant juvenile learning.

During a juvenile sensitive period, songbirds memorize one or more tutor songs that they gradually learn to imitate through vocal rehearsal (Catchpole and Slater, 1995). In some songbird species, including swamp sparrows, juveniles learn to produce

Received Dec. 4, 2009; revised June 15, 2010; accepted June 17, 2010

This research was supported by funding from National Institutes of Health Grants DC02524 and NSF 0821914 . We are grateful to William A. Searcy, Rindy C. Anderson, Casey Klofstad, Schuyler Nowicki, Mike Kiehart, and Sarah Butters for assistance in collecting and hand-rearing nestling birds, and to David Kloetzer for assistance in neurophysiological experiments.

Correspondence should be addressed to Richard Mooney, Department of Neurobiology, Duke University Medical Center, Room 427D, Bryan Research Building, Durham, NC 27710. E-mail: mooney@neuro.duke.edu.

DOI:10.1523/JNEUROSCI.6042-09.2010

Copyright $\odot 2010$ the authors $\quad 0270-6474 / 10 / 3010586-13 \$ 15.00 / 0$ many acoustically distinct songs, some of which they subsequently discard, yielding a much smaller adult repertoire (Marler and Peters, 1982a, 1988). This developmental progression provides a powerful context in which to examine whether the adult brain contains a record of experience associated with transiently performed behaviors (Geberzahn et al., 2002).

A potential challenge to this examination is locating neurons that might contain such a lasting record. Songbirds possess a network of brain nuclei specialized for song learning, performance, and perception (Nottebohm et al., 1976). Within this "song system," the telencephalic nucleus HVC is a site where motor and auditory representations of song merge. HVC neurons display song motor-related activity and also can be excited by auditory presentation of the bird's song (McCasland and Konishi, 1981; Margoliash, 1986; Yu and Margoliash, 1996; Mooney et al., 2001; Hahnloser et al., 2002; Prather et al., 2008). Furthermore, HVC receives auditory input from the caudal portion of the mesopallium (Bauer et al., 2008), a region implicated in song memories and perception (Bolhuis and Gahr, 2006). These features suggest HVC may contain a lasting record of songs experienced and copied during juvenile development but not retained in the adult repertoire.

To identify songs that were learned and performed only transiently, we tutored juvenile swamp sparrows using a suite of swamp sparrow songs and extensively recorded each bird's juvenile and adult singing. We then anesthetized those birds and recorded extracellular responses in HVC to playback of songs in the bird's adult repertoire, tutor songs, and novel swamp sparrow songs. In addition to responding to songs in the adult repertoire, HVC neurons commonly responded even more robustly to tutor songs that had served as models for songs performed only tran- 


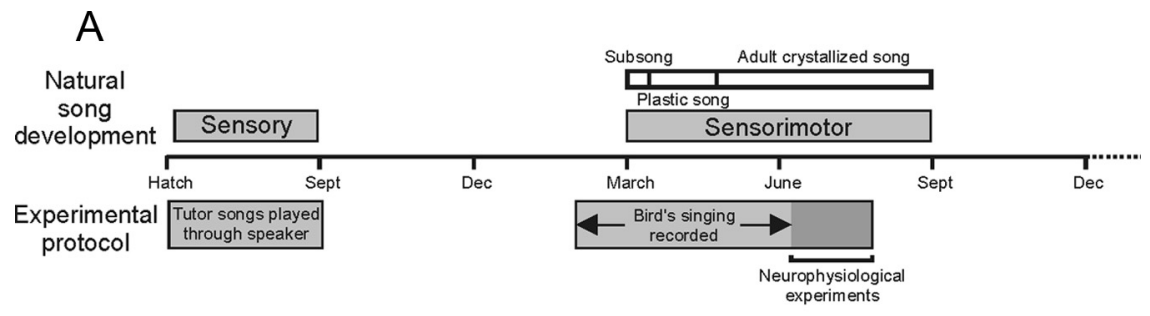

B
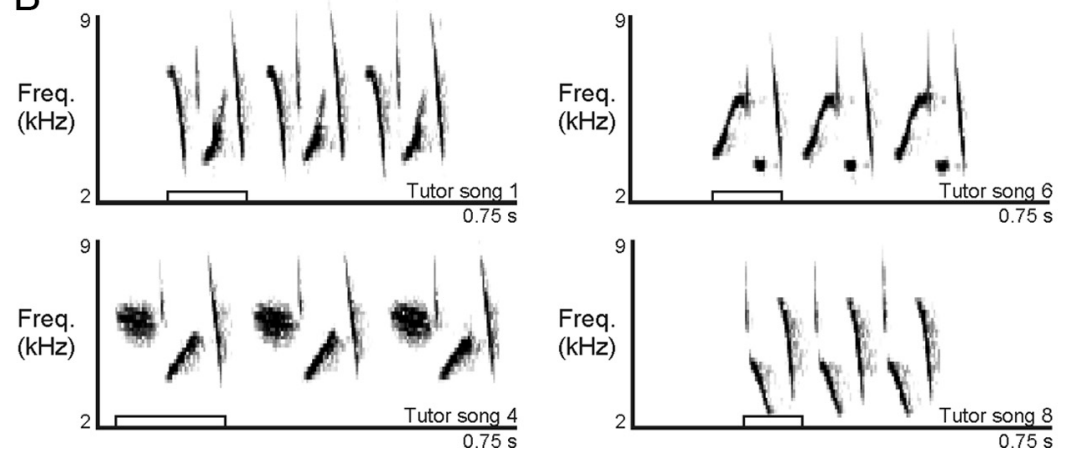

Figure 1. Swamp sparrows heard tutor songs only during juvenile development. $A$, During the sensitive period of their first year of life, swamp sparrows memorize the songs they later recall and perform as adults, and those songs are stored in memory until the birds begin to sing in the following year (Marler and Peters, 1981) (top). In this study (bottom), nestlings were collected from the wild at $\sim 5 \mathrm{~d}$ of age and tutored in the laboratory using 21 conspecific songs ("tutor" songs). Each bird's vocalizations were documented during sensorimotor song development ("subsong" and "plastic" song) and beyond vocal maturation ("crystallized" song). After each bird's auditory and vocal life history had been documented, adult birds were anesthetized and neural responses to song stimuli were recorded. $\boldsymbol{B}$, Tutor songs consisted of trilled multinote syllables (open boxes; song duration, $\sim 2 \mathrm{~s}$; truncated for clarity) that were distinct in their spectrotemporal structure.

siently during juvenile life. Effective tutor songs were not simply those that were acoustically similar to songs in the adult's repertoire, suggesting HVC retains a lasting record of experience associated with behaviors performed only transiently during juvenile life.

\section{Materials and Methods}

All experiments were performed in compliance with federal regulations governing the capture and use of wild birds and in accordance with protocols regarding housing and procedure that were approved by the Duke University Institutional Animal Care and Use Committee.

Subjects. We collected swamp sparrows as nestlings from Crawford County, Pennsylvania, and raised them by hand in the laboratory in a large sound isolation room (Marler and Peters, 1988) $(N=6$ male birds collected May 31, 2007; average age at time of collection, $5 \mathrm{~d}$ after hatch). Beginning at $18 \mathrm{~d}$ after hatch, birds were given seed and water ad libitum, and hand-feeding was continued as necessary until each bird was feeding completely independently ( $\sim 22 \mathrm{~d}$ after hatch). Throughout their time in the laboratory, the birds experienced a varying photoperiod that was changed weekly to emulate the natural photoperiod. The seasonal progression of song development in the birds studied here followed the pattern observed in previously studied laboratory-raised swamp sparrows (Marler and Peters, 1982c) (Fig. 1A).

Presentation of song stimuli to juvenile birds. Beginning at $\sim 6 \mathrm{~d}$ after hatch, all birds were tutored with the same set of 21 different swamp sparrow songs. As part of a learning experiment designed to investigate the influence of variety on song learning and perception, which is not relevant to the present analysis, we presented two exemplars each [one "high-performance" and one "low-performance," defined by Ballentine et al. (2004) and DuBois et al. (2009)] from seven different song type categories and one song exemplar from an additional seven song type categories. There was no difference between the observed distribution of song types that birds eventually performed in crystallized song and the expected distribution among the three groups of stimuli (seven uniquely presented song types, seven high-performance variants, seven low- performance variants; $\chi^{2}=1.9, p>0.05$ ), indicating that the set of songs that each bird imitated was not affected by the tutoring regimen. Model songs were selected from recordings of male birds in the same breeding population from which the nestlings were collected, and we intentionally chose songs that were acoustically distinct from each other (Fig. 1B) (quantified in Results) to ensure that we could unambiguously identify the songs that served as models for the young birds' imitation. Training songs were presented in $3 \mathrm{~min}$ bouts of a single song type played once every $10 \mathrm{~s}$, with $1 \mathrm{~min}$ of silence between each bout (Marantz PMD 660 Recorder and Acoustic Research Powered Partners Speaker), comparable with the rate of natural singing in the wild. Over a training period of 12 weeks, the 21 bouts were played once in the morning and once in the afternoon and were presented in a random order that changed every week (June 1, 2007 through August 23, 2007). This period spans the sensory phase of swamp sparrow song learning during which birds memorize the songs that they will later recall and sing as adults (Marler and Peters, 1988) (Fig. 1A). Swamp sparrows are seasonal in their singing behavior, with robust singing occurring only during the spring and early summer, and songs that birds learn during the juvenile sensory period are stored in memory without rehearsal until the following winter when the birds begin to sing (Marler and Peters, 1981) (Fig. 1A).

Documenting song development. To document the birds' song development, we recorded each bird in an individual sound isolation chamber (Industrial Acoustics; Shure SM-57 microphone; Edirol USB Audio Capture UA-1000; Sound Analysis Pro software; songs digitized at 44,100 $\mathrm{Hz}$ ) on a weekly basis beginning at $\sim 250 \mathrm{~d}$ of age (recordings began the first week of February 2008) (Fig. 1 A), and we visually identified all songs that were recorded. Subsong, a form of singing in which sound production is so variable that no stereotyped features, and thus no evidence of vocal imitation, can be detected (Marler and Peters, 1982c), was first recorded in the end of February. Each bird was recorded intensively (once per week for a period of $23.6 \pm 0.3$ contiguous hours per week) to generate a detailed record of the bird's vocal development from subsong through the emergence of identifiable syllables, a stage called "plastic song" (Marler, 1956; Marler and Peters, 1982b,c), to the expression of trills of stereotyped syllables, which is the "crystallized song" that typifies adult behavior (Marler and Peters, 1982c) (Fig. 1A). Although these methods leave open the possibility that a song type sung extremely rarely and intermittently may have been missed by our recording paradigm, we sampled far more examples of plastic song per bird (1822 \pm 485 songs per bird) than were typically necessary to define the total repertoire of song types that each bird produced during plastic song (397 \pm 240 songs per bird) (supplemental Fig. 1, available at www.jneurosci.org as supplemental material). These data support our assertion it is likely that song types that were never detected in our recordings of a particular bird were never performed by that bird.

To determine which training songs were imitated throughout the development of each bird's vocal repertoire, spectrograms of each bird's plastic and crystallized vocalizations were compared against spectrograms of the tutor songs that had been heard during sensory learning. The syllables that define different song types are clearly distinguishable (Fig. $1 B$ ), and those differences are typically evident even in plastic song (see Fig. $2 \mathrm{~A}$ ), enabling reliable classification of a vocalization as an imitation of a certain tutor song type. The average spectrographic crosscorrelation among all pairwise comparisons of tutor syllables was $0.34 \pm$ 0.01 (mean \pm SE). The average cross-correlation between the seven pairs 
of tutor songs for which two variants were presented was higher $(0.49 \pm$ 0.06 ), as would be predicted, but those variants were sufficiently distinct that the birds' performances could be reliably identified as copies of one or the other song variant in each pair.

Neurophysiological recordings. We performed electrophysiological experiments after the birds were fully adult and had been singing crystallized songs for at least 6 weeks ( $\sim 400 \mathrm{~d}$ of age; all experiments performed between June 11, 2008 and July 24, 2008; each bird's vocal behavior was recorded intensively from the first week of February 2008 through the first week of June, encompassing an average of 6.5 weeks of crystallized song). The set of acoustic stimuli for each bird consisted of digitized recordings of all of the song types in the bird's commonly performed (see below) adult repertoire ("adult repertoire" songs), a large number of songs that the bird had been tutored with during its sensitive phase ("tutor" songs), and a set of novel songs that were recorded from adult males of the population from which the nestling birds had been collected but to which the birds had not been exposed previously ("novel" songs). Because of technical and practical constraints on the number of song stimuli that could be tested for each cell ( $>1 \mathrm{~h}$ to test each cell), not all tutor songs were tested in every cell, but each cell was tested with all of the commonly performed song types in the bird's adult repertoire, at least 14 of the 21 tutor songs that the bird had experienced during development $(15.9 \pm 0.8$ tutor songs per cell), and at least 6 novel songs $(7.0 \pm 0.2$ novel songs per cell; mean \pm SE). Although each bird was presented with some or all of the same set of novel songs, the set of tutor songs varied across individuals to ensure that most tutor songs that the bird had imitated at any stage of development were included in its stimulus set.

A detailed account of anesthetic and electrophysiological methods has been published previously (Mooney et al., 2001). Briefly, birds were anesthetized with $20 \%$ urethane ( $120 \mu \mathrm{l}$, i.m.), and a steel post was glued to the skull to fix the bird in a stereotaxic device. All recordings were performed inside a sound-attenuating chamber (Industrial Acoustics) on a vibration isolation table (TMC), and the bird was warmed using an electric blanket (Harvard Apparatus). A small craniotomy was made over the target structure [nucleus HVC; abbreviation used as a proper noun (Jarvis et al., 2005)], and the dura was retracted with a fine insect pin. A hydraulic microdrive (Soma Scientific) was used to lower an extracellular electrode (Carbostar-1; Kation Scientific) to the recording site, and extracellular voltage was amplified (A-M Systems), bandpass filtered (500 $\mathrm{Hz}$ to $5 \mathrm{kHz}$ ), digitized $(10 \mathrm{kHz})$, and stored onto a hard drive (National Instruments; software written by M. Rosen, F. Livingston, and R. Balu, Duke University, Durham, NC). HVC neurons could be distinguished from the surrounding structures by the pattern of their intrinsic discharge and their responses to auditory stimuli, and all recording locations were verified histologically at the end of each experiment. The auditory response of a neuron was tested if its action potential was of sufficient size to permit reliable discrimination and sorting, regardless of whether the neuron responded to playback of any song in the adult repertoire. Twenty iterations of each song stimulus, delivered once every 6-8 s, were presented at $70 \mathrm{~dB}$ (RMS, A-weighting) through a speaker placed $20 \mathrm{~cm}$ away directly in front of the bird.

Data analysis: neurophysiological activity. The fact that song development studies with wild sparrows take in excess of a full year to complete required that we collect as much data as possible during the terminal electrophysiological experiment for each bird. Therefore, we chose to sample multiunit data and later sort action potentials into records of single-unit activity based on waveform characteristics [WaveClus (Quiroga et al., 2004)]. Experience has taught us, however, that it can be difficult to reliably discriminate the action potentials of more than two units in the same recording. Therefore, we attempted to sample data in which action potentials from only one or two units were clearly distinguishable. Discrimination of individual neurons was verified by the presence of a refractory period in the interspike interval histogram for each cell (no intervals $<1 \mathrm{~ms}$ ), a technique that we have used successfully to discriminate the activity of individual neurons in HVC of swamp sparrows (Prather et al., 2008). Peristimulus time histograms (10 ms bin size) were constructed for the response of each cell to each stimulus, and paired $t$ tests were used to assess whether the suprathreshold responses of the neuron to song differed significantly from the baseline firing rate (response strength; the same duration of response and baseline conditions was used to compare the response to each stimulus in each cell). The song in the bird's adult repertoire that evoked the strongest significant response in each cell was deemed the "strongest adult song type" for that cell. Thus, for each cell, there was one strongest adult song type, but different cells within the same bird could respond most strongly to different songs in the bird's adult repertoire, consistent with our previous findings on this species (Prather et al., 2008).

The response of each cell to its strongest adult song type was used as a standard for comparing the responses of that cell to tutor and novel songs. The selectivity of a given neuron for the strongest adult song type versus other stimuli was measured using the psychophysical metric $d^{\prime}$, a value that compares the relative strengths of two responses, accounting for both the difference between the means and the variance present in each response (Green and Swets, 1966; Mooney et al., 2001). The values of $d^{\prime}$ can be either positive or negative, and a positive value in the present calculations indicates a greater response to the strongest adult song type than to the test stimulus being compared. A $d^{\prime}$ value of $>0.7$ was used as the criterion for identifying responses to the strongest adult song type that were significantly greater than the response to the test stimulus (Green and Swets, 1966; Mooney et al., 2001), and a $d^{\prime}$ value of less than -0.7 indicated responses that were significantly greater to the test stimulus than to the strongest adult song type. Numbers of cells and numbers of birds are reported, and all statistical comparisons of neurophysiological data are based on the number of cells unless otherwise noted.

Data analysis: comparison of acoustic features among song stimuli. We observed that individual neurons responded to multiple song stimuli (see Results). Interpreting this finding required that we resolve whether a given cell was responding to multiple acoustically distinct songs, or whether that cell was responding to a particular acoustic feature that was shared across multiple songs. Because swamp sparrow songs consist of a syllable that is trilled many times with very high stereotypy (Marler and Peters, 1982c), the spectrotemporal structure of a song can be represented by the structure of a representative syllable. Following the comparisons made in our analysis of neurophysiological data, we focused our analysis of the acoustic features of songs that evoked significant responses in a given cell ("effective" stimuli) versus the songs that failed to elicit a significant response in the same cell ("ineffective" stimuli) using the strongest adult song type of the cell as a standard for comparison. We used pairwise spectrographic cross-correlation to compare the acoustic structure of the strongest adult song type versus all effective stimuli, and we compared that same strongest adult song type versus all ineffective stimuli (Signal for Windows sound analysis software; Engineering Design; sampling rate, 44,100 Hz; 256 pt fast Fourier transform) (for more information regarding spectrographic correlation, see Clark et al., 1987; Nowicki et al., 2002). We also performed the same comparisons using a dynamic time warping algorithm as an additional means of assessing spectrographic similarity [Luscinia; http://luscinia.sourceforge.net (Lachlan et al., 2010)]. These comparisons allowed us to ask whether acoustic similarity could account for the responses of an individual neuron to multiple song types by testing whether the set of effective stimuli were more like the strongest adult song type than the ineffective stimuli in each cell.

We also considered that, even though the strongest adult song type was a very efficacious stimulus in a given cell, there might also exist another stimulus that could drive the cell even more strongly and could thus serve as a better standard for comparing acoustic features of effective and ineffective stimuli. Therefore, we repeated the previously described comparisons of effective and ineffective stimuli, but in this instance we compared those stimuli using as a standard the stimulus that drove the strongest response in the cell, even if that maximally efficacious stimulus was not part of the bird's repertoire of commonly produced adult songs. Finally, we also considered that the spectrotemporal features shared by two syllables might not span the entire syllable and thus could be obscured in our comparisons between full syllables. Therefore, we further compared each individual note in the syllable of the strongest adult song type (or other reference standards described above) against all other notes in every other syllable. As before, we compared the acoustic similarity between the standard and the set of effective stimuli versus the 
A
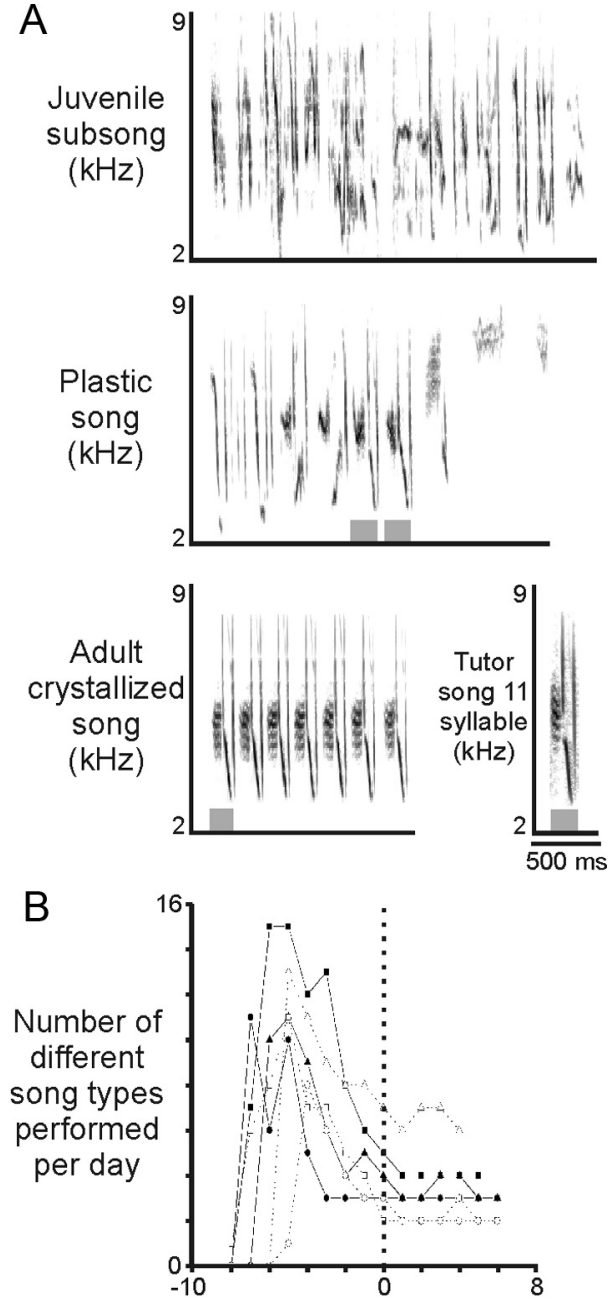

Weeks relative to crystallization

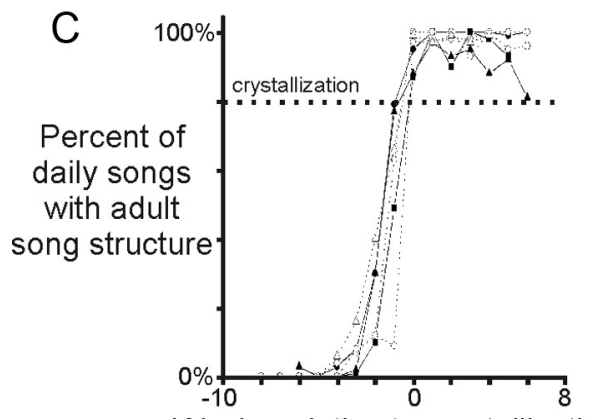

Weeks relative to crystallization

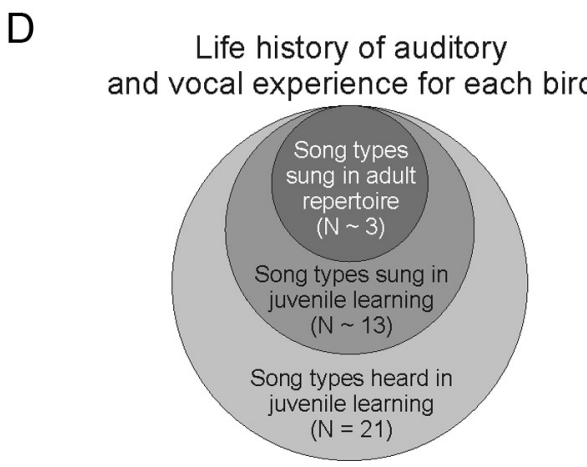

Figure 2. Juvenile swamp sparrows develop their adult song repertoire through a process of juvenile overproduction and attrition. $A$, Songs performed during development were classified similarity between the standard and the set of ineffective stimuli. Together, these comparisons of syllables and individual notes allowed us to address whether or not the activity of a given neuron represented responsiveness to multiple acoustically distinct songs.

\section{Results}

\section{Juvenile song repertoires undergo overproduction} and attrition

Previous studies of song learning in swamp sparrows show that the transition from acoustically variable "plastic" juvenile song to highly stereotyped adult song, a process referred to as "song crystallization," is also marked by a pronounced reduction in the number of song types in an individual's repertoire (Marler and Peters, 1982a,c). Consistent with this previous work, we found that our subjects produced clearly recognizable imitations of five times as many tutor song types in their juvenile repertoire of plastic songs (Fig. $2 A-C)(N=12.8 \pm 1.2$ song types) than they did in their adult repertoire of commonly produced crystallized songs (Fig. $2 A-C)(N=2.5 \pm 0.2$ song types; mean \pm SE; range of $N$ plastic song types per bird, 9-18; range of song types in each bird's adult repertoire, 2-3). During the plastic song phase, all juveniles studied here imitated only a subset of tutor songs to which they were exposed, and all songs that became part of the adult crystallized repertoire were sung previously in some form of plastic song, consistent with previous results (Marler and Peters, 1982c) (Fig. 2 B; supplemental Fig. 1, available at www.jneurosci. org as supplemental material). Thus, each bird's developmental history provided a natural categorization of tutor songs as those that the bird (1) performed imitations during plastic song and retained as part of its adult repertoire; (2) performed imitations during plastic song but eliminated from its adult repertoire; and (3) apparently never imitated, because those song types were never detected in our record of the bird's vocalizations (Fig. 2D).

Through the use of automated recording techniques (Tchernichovski et al., 2000), we documented not only the commonly produced crystallized songs that defined each bird's adult repertoire but also the crystallized songs that were produced very rarely. "Commonly performed" crystallized songs that defined the adult repertoire constituted $99.0 \pm 0.4 \%$ (mean \pm SE) of all crystallized performances by each bird ( $N=15$ song types, 6 birds; $1991 \pm 207$ performances during the crystallized period of each song type in the adult repertoire), whereas "rarely performed" crystallized songs constituted only $1.0 \pm 0.4 \%$ of all crystallized songs sung $(N=11$ rare song types from five birds; $1.8 \pm 0.7$ rare song types per bird; the $1.0 \pm 0.4 \%$ of songs sung referred to above translates in real numbers to $18 \pm 9$ perfor-

\footnotetext{
$\leftarrow$

as juvenile subsong (top), juvenile plastic song (middle), or adult crystallized song [bottom left, songs from the same bird depicted in each panel; developmental criteria defined by Marler and Peters (1982a)]. Because imitation of tutor songs could be discerned in plastic and crystallized songs (gray boxes indicate similar syllables), those songs were further characterized as plastic or crystallized performances of the bird's copy of the corresponding tutor song (bottom right). $B, C$, Vocal maturation was characterized by a reduction in the number of distinct song types that a bird performed each day (all 6 birds shown) (B) and an increasing proportion of crystallized songs in the bird's daily vocal output ( $($ ). The transition from the juvenile "plastic state" into the adult "crystallized state" was defined as the first day on which the bird sang $>80 \%$ of its daily song output as crystallized songs (dotted horizontal line). This transition was typically rapid, and production of predominantly crystallized songs persisted after crystallization (all 6 birds shown). $\boldsymbol{D}$, Each bird's auditory and vocal life history could be summarized as a Venn diagram. During development, each bird heard the same set of 21 tutor songs (outer circle), imitated only a portion of those tutor songs in the juvenile state (middle circle), and retained only a subset of those juvenile song types as its adult song repertoire (inner circle). All songs that were part of the adult repertoire were also performed during juvenile learning.
} 
mances recorded; mean $\pm \mathrm{SE}$ ). In the remainder of this paper, we consider a bird's adult repertoire to be the same as its repertoire of "commonly produced" song types. There was no difference in the quality of copying for commonly performed songs in the adult repertoire $(0.68 \pm 0.03)$ versus songs that were rarely performed in adulthood $(0.67 \pm 0.03 ; p=0.80$, spectrographic correlation coefficient, $t$ test).

This pattern of expressing both commonly performed and rarely performed crystallized song types was also evident in another cohort of swamp sparrows that we have raised by hand and recorded in each of 5 consecutive years ( $N=10$ birds) (S. Peters, unpublished data). The repertoires of those birds were extremely stable across years, with all but one commonly performed song types in one year also being commonly performed in subsequent years. Among those 10 birds, 8 sang rarely performed song types (same definition as above) during their first year $(1.5 \pm 0.2$ rare song types per bird), and all of those song types identified as rare were detected as rare song types in the following year (66\% of rare songs detected during the first year of song were also detected during the fifth year). Furthermore, songs identified as rare song types in the first year never became commonly performed repertoire songs in subsequent years. Together, these observations strengthen our categorization of crystallized song types into commonly performed and rarely performed groups.

\section{HVC neurons respond to playback of songs in the bird's adult repertoire}

We used extracellular recordings in urethane-anesthetized adult male swamp sparrows to characterize the auditory responses of individual unidentified HVC neurons to playback of songs in the bird's adult repertoire, tutor songs that the bird heard only during juvenile development, and novel swamp sparrow songs (Fig. $3 A-D)$. In agreement with previous descriptions of HVC auditory responses in wild-caught swamp sparrows (Mooney et al., 2001; Prather et al., 2008, 2009), individual neurons were strongly responsive to auditory presentation of one or more songs in the bird's adult repertoire (Fig. 3C). Significant increases in activity were evoked by one or more adult songs in 20 of 23 cells (six birds), 1 cell expressed no significant response to any adult song type, and 2 cells significantly decreased their activity in response to adult songs (two birds) (supplemental Fig. 2, available at www.jneurosci.org as supplemental material). Furthermore, the HVC neurons we sampled were uniformly more strongly excited by forward than reverse playback of effective songs (Fig. $3 C$ ), confirming previous observations that HVC responses are sensitive to the temporal sequence of acoustic features in the song (Margoliash and Fortune, 1992; Lewicki and Konishi, 1995; Lewicki, 1996).

Individual HVC neurons typically expressed significant responses to multiple song types in the adult repertoire. Sixteen of 20 cells (six birds) responded to the complete adult repertoire $(N=2.5 \pm 0.2$ songs), and on average cells responded to $2.25 \pm$ 0.14 songs ( $91 \pm 4 \%$ of the bird's adult repertoire), a broad selectivity that could reflect the sampling of particular cell types [i.e., interneurons of urethane-anesthetized swamp sparrows have previously been shown to respond to multiple song types (Mooney et al., 2001)]. Although individual HVC neurons could respond to multiple song types in the adult repertoire, each HVC neuron responded more strongly to one adult song type than to all others in the repertoire, which we refer to here as the strongest adult song type for that cell (Fig. 3C) (see Materials and Methods). The identity of that strongest adult song type varied across cells, but the responses of an individual neuron were consistent
A
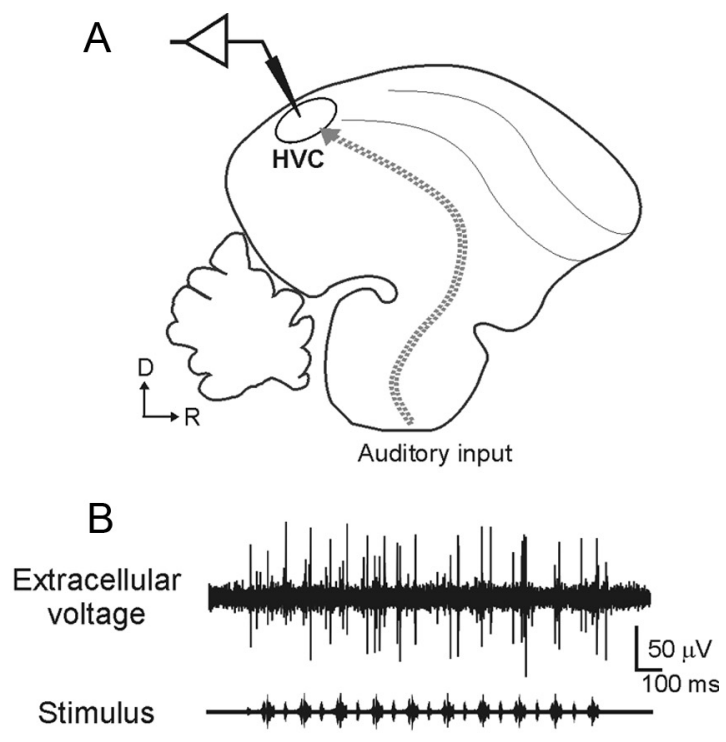

C $\begin{array}{r}\text { Repertoire } \\ \text { song type A }\end{array}$

Repertoire song type $B$
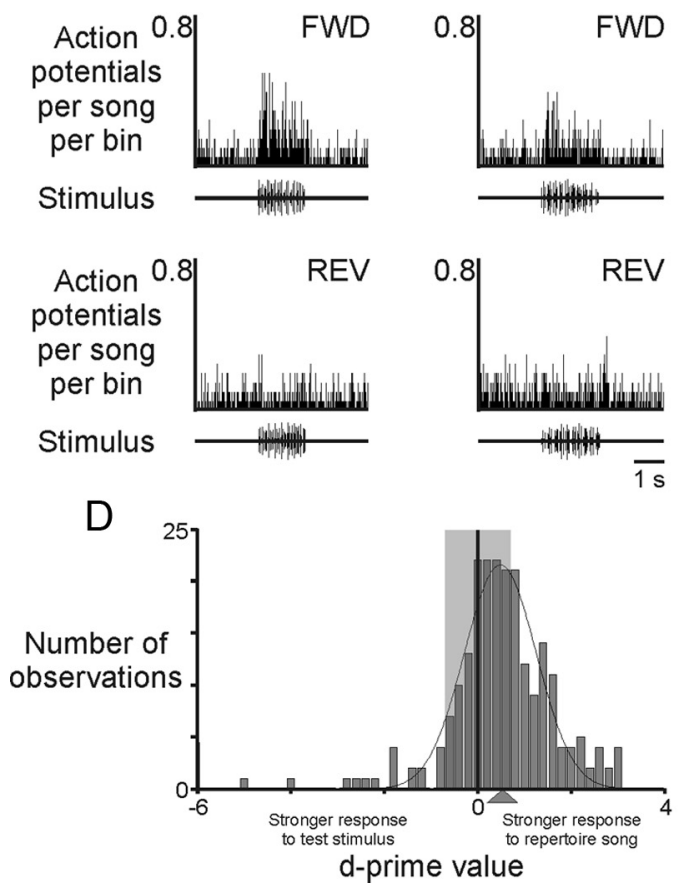

Figure 3. HVC neurons respond robustly to songs in the adult repertoire. $A$, Electrophysiological activity was recorded extracellularly from individual HVC neurons in anesthetized adult male swamp sparrows (parasagittal schematic of the swamp sparrow brain showing the telencephalic nucleus HVC and its auditory inputs, collectively represented as a dotted arrow). $\boldsymbol{B}$, Multiunit auditory responses (top) to presentation of song stimuli (bottom) was collected and sorted off-line into records of single-unit activity [WaveClus (Quiroga et al., 2004)] (see Materials and Methods). C, As reported previously for HVC neurons in anesthetized swamp sparrows (Mooney et al., 2001), HVC neurons responded robustly and selectively to songs in the adult repertoire, with strong responses to forward playback of those songs (FWD, top) but little or no response to reverse playback of the same songs (REV, bottom; peristimulus time histogram bin size, $10 \mathrm{~ms}$; song stimuli shown as oscillograms). D, Across the population of all HVC neurons sampled in all birds, songs in the adult repertoire evoked stronger responses than the set of all conspecific tutor and novel songs [mean $d^{\prime}$ value of Gaussian fit (solid line) $=0.48, p=0.004$, Wilcoxon's signed rank test, 20 cells, 6 birds; positive $d^{\prime}$ values indicate a stronger response to the strongest adult song type (Mooney et al., 2001); the shaded region indicates $d^{\prime}$ values between -0.7 and 0.7$]$. 
A

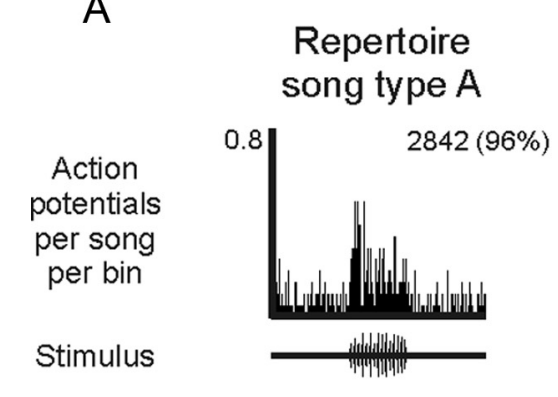

B
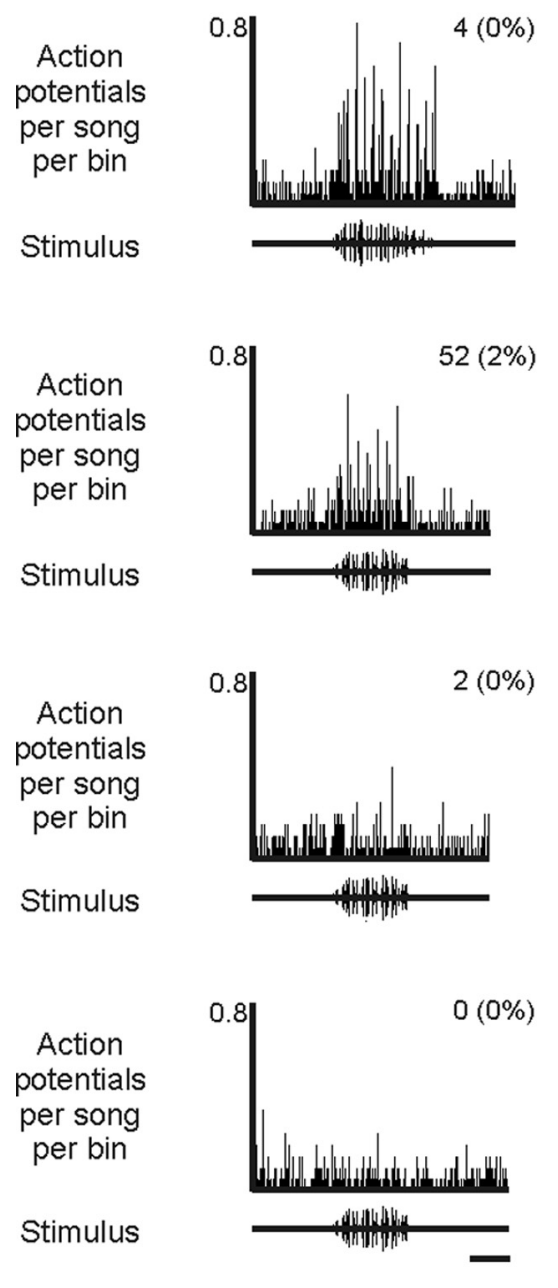

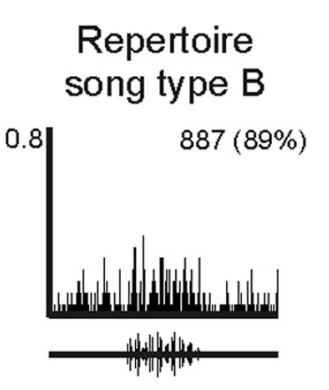

C

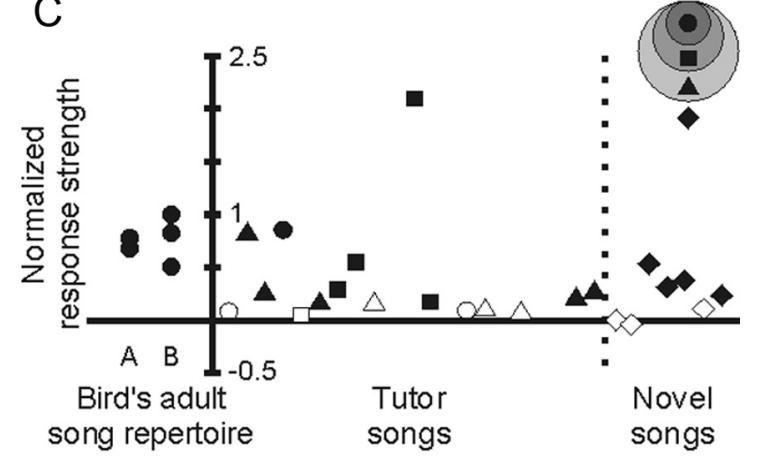

Novel songs
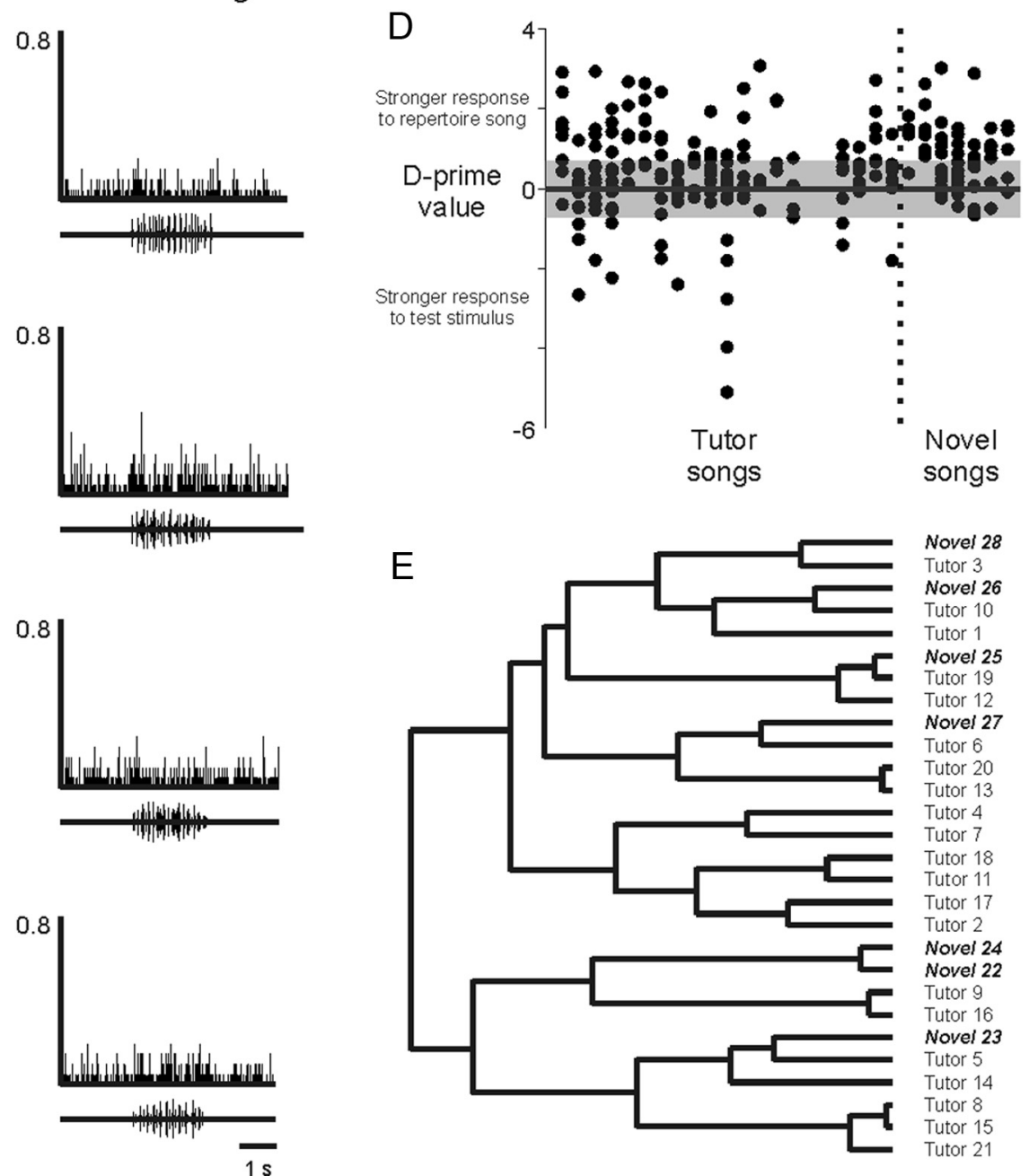

Figure 4. Individual HVC neurons respond not only to songs in the adult repertoire but also to tutor songs. The same HVC neuron depicted in Figure $2 B$ responded vigorously to both songs in the adult repertoire $(\boldsymbol{A})$ and tutor songs that the bird had heard during development $(\boldsymbol{B}$, left) but not to novel songs ( $\boldsymbol{B}$, right; numbers in the top right indicate the number of times the bird performed its copy of that tutor song and the percentage of those performances that occurred in the adult crystallized state). The robust representation of tutor songs, often the strongest response of a cell to any stimulus [e.g., top left peristimulus time histogram (PSTH) in $B$ ], could be evoked by tutor songs that the bird sang only during the plastic state of song development (top left PSTH; $N=4$ lifetime performances; $0 \%$ in crystallized state). Notably, this response did not generalize across all songs that were sung in the juvenile state, as another tutor song that was also performed during juvenile song was not effective in activating the cell (third left PSTH; $N=2$ songs in plastic state). $C$, This panel shows the complete response profile of the cell depicted in $A$ and $B$ for all adult, tutor, and novel song stimuli. The symbols indicate the role of the song in the bird's life history as in Figure 2D; the dotted vertical line separates responses to tutor and novel songs; filled symbols, significant response strengths; open symbols, responses that were not significant. $\boldsymbol{D}$, Tutor songs commonly evoked responses that were significantly greater than the response of the same cell to songs in the adult repertoire (defined as outside of the shaded region; $N=9$ song types, 9 cells, 5 birds), but no such response was observed for novel songs. This difference likely reflects the relevance of tutor songs in the bird's life history (symbols indicate the role of the song in the bird's life history as in Fig. $1 E$; dotted vertical line separates responses to tutor and novel songs; $d^{\prime}<-0.7$ indicates significantly stronger response to test stimulus; the shaded region indicates $d^{\prime}$ values considered not significantly different from zero; range, -0.7 and 0.7 ; responses to $20 \mathrm{HV}$ ( neurons shown). $\boldsymbol{E}$, There was no systematic difference in acoustic structure of tutor and novel songs, evident in the distribution of novel songs (bold italics) throughout this phenogram of the stimuli used in these experiments (difference in acoustic structure is related to the distance between songs, analysis performed using custom software [Luscinia, http://luscinia.sourceforge.net; (Lachlan et al., 2010)]; adult repertoire songs for each bird excluded). 


\begin{tabular}{|c|c|c|c|c|c|c|c|c|c|c|c|c|c|}
\hline \multirow[b]{3}{*}{ Bird } & \multirow[b]{3}{*}{$\begin{array}{l}\text { Cell } \\
\text { index }\end{array}$} & \multicolumn{12}{|c|}{ Tutor song types for } \\
\hline & & \multicolumn{3}{|c|}{$\begin{array}{l}\text { Adult repertoire (common song } \\
\text { types) }\end{array}$} & \multicolumn{3}{|c|}{ Rare adult song types } & \multicolumn{3}{|c|}{ Songs sung only in plastic song } & \multicolumn{3}{|c|}{$\begin{array}{l}\text { Songs never detected in bird's } \\
\text { vocalizations }\end{array}$} \\
\hline & & $\begin{array}{l}\text { Song types } \\
\text { imitated }\end{array}$ & $\begin{array}{l}\text { Song types } \\
\text { presented }\end{array}$ & Responses & $\begin{array}{l}\text { Song types } \\
\text { imitated }\end{array}$ & $\begin{array}{l}\text { Song types } \\
\text { presented }\end{array}$ & Responses & $\begin{array}{l}\text { Song types } \\
\text { imitated }\end{array}$ & $\begin{array}{l}\text { Song types } \\
\text { presented }\end{array}$ & Responses & $\begin{array}{l}\text { Song types } \\
\text { never detected }\end{array}$ & $\begin{array}{l}\text { Song types } \\
\text { presented }\end{array}$ & Responses \\
\hline \multicolumn{14}{|c|}{ Cells with maximum response to an adult repertoire song type } \\
\hline sw602 & 1 & 3 & 3 & & 2 & 2 & & 13 & 10 & & 3 & 2 & \\
\hline sw613 & 2 & 2 & 2 & & 1 & 0 & & 10 & 8 & & 8 & 5 & \\
\hline sw607 & 3 & 3 & 3 & & 0 & 0 & & 9 & 9 & & 9 & 4 & \\
\hline sw607 & 4 & 3 & 3 & & 0 & 0 & & 9 & 9 & & 9 & 3 & \\
\hline sw609 & 5 & 2 & 2 & & 2 & 2 & & 8 & 8 & & 9 & 4 & \\
\hline sw609 & 6 & 2 & 2 & & 2 & 2 & & 8 & 8 & & 9 & 4 & \\
\hline \multicolumn{14}{|c|}{ Cells with maximum response to a tutor song type, but not significantly greater than response to strongest adult song type } \\
\hline sw607 & 7 & 3 & 3 & 1 & 0 & 0 & & 9 & 9 & & 9 & 4 & \\
\hline sw607 & 8 & 3 & 3 & 1 & 0 & 0 & & 9 & 9 & & 9 & 3 & \\
\hline sw609 & 9 & 2 & 2 & 1 & 2 & 2 & & 8 & 8 & & 9 & 4 & \\
\hline sw617 & 10 & 3 & 1 & & 5 & 4 & 1 & 5 & 4 & & 8 & 5 & \\
\hline sw616 & 11 & 2 & 2 & & 1 & 1 & & 6 & 6 & 1 & 12 & 7 & \\
\hline \multicolumn{14}{|c|}{ Cells with maximum response to a tutor song type, significantly greater than response to strongest adult song type } \\
\hline sw602 & 12 & 3 & 3 & 1 & 2 & 2 & & 13 & 10 & & 3 & 2 & \\
\hline sw609 & 13 & 2 & 2 & 1 & 2 & 2 & & 8 & 8 & & 9 & 4 & \\
\hline sw617 & 14 & 3 & 3 & 1 & 5 & 4 & 2 & 5 & 4 & & 8 & 6 & 2 \\
\hline sw602 & 15 & 3 & 3 & & 2 & 2 & 1 & 13 & 10 & & 3 & 2 & \\
\hline sw617 & 16 & 3 & 3 & & 5 & 4 & 1 & 5 & 4 & & 8 & 6 & \\
\hline sw616 & 17 & 2 & 2 & & 1 & 1 & 1 & 6 & 6 & 2 & 12 & 7 & 1 \\
\hline sw613 & 18 & 2 & 2 & & 1 & 0 & & 10 & 8 & 1 & 8 & 5 & \\
\hline sw616 & 19 & 2 & 2 & & 1 & 1 & & 6 & 6 & 1 & 12 & 7 & \\
\hline sw613 & 20 & 2 & 2 & & 1 & 0 & & 10 & 8 & 2 & 8 & 5 & \\
\hline
\end{tabular}

across repeated presentations of that song. Therefore, the strongest adult song type for each cell was used as a standard for comparing the responses of that neuron to songs in the adult repertoire versus other tutor and novel songs.

We examined the auditory responses of HVC neurons in our laboratory-raised birds to determine whether those cells expressed stronger responses to songs in the bird's adult repertoire than to other swamp sparrow songs, as reported for wild sparrows (Margoliash and Konishi, 1985; Margoliash, 1986; Mooney et al., 2001; Prather et al., 2008). To do this, we compared the auditory responses of each HVC neuron to its strongest adult song type versus responses of the same cell to all other conspecific songs, temporarily ignoring the distinction between novel conspecific songs and those that had served as tutor songs. Consistent with previous reports, we observed that the population of HVC neurons was more strongly responsive to the bird's adult song types than to this panel of conspecific songs (Fig. 3D).

Individual HVC neurons typically respond more strongly to a tutor song than to any song in the adult repertoire

Although HVC neurons collectively responded to songs in the adult repertoire more strongly than the collection of all tutor and novel songs, notable exceptions to that trend were evident in the responses of individual neurons to specific tutor songs (Fig. 4). Among the 20 of 23 cells that significantly increased their firing rate in response to adult song, 14 cells (70\%) responded even more strongly to a tutor song type (Fig. $4 A-C$, Table 1). Furthermore, the tutor song type that evoked the maximal response was not simply similar to any song type in the bird's adult repertoire. In fact, the maximally effective tutor song type was a model for any song type in the adult repertoire in only 6 of 14 cells (43\%), and in only 2 of these 6 cells ( 2 cells of 14, or 14\%) was the tutor song type also the model for the strongest adult song type of the neuron. Therefore, a tutor song type from the bird's past was the maximally excitatory stimulus in 14 of 20 cells that significantly increased their firing in response to an adult song type (17 of 23 cells overall) (see below), and that tutor song type was not a model for any song in the bird's adult repertoire in 9 of 14 cells $(64 \%)$.

The psychophysical metric $d^{\prime}$ was used to determine the cases in which the response of a neuron to a tutor song was significantly greater than the response of the same cell to its strongest adult song type [considered significant if $d^{\prime}<-0.7$ (Green and Swets, 1966; Mooney et al., 2001) (supplemental Fig. 3, available at www.jneurosci.org as supplemental material)]. The response to one or more tutor songs significantly exceeded the response to any song in the bird's adult repertoire in 9 of 20 cells (five birds) (Table 1). An example of such a response is shown in Figure 4. The cell in Figures $4 A-C$, the same cell shown in Figure $3 B$, responded to both song types in the bird's adult repertoire (Fig. $4 A$ ), but the response to a tutor song significantly exceeded the response to the strongest adult song type for that cell (Fig. $4 B, C$ ). Notably, the robust responses that could be elicited by certain tutor songs did not reflect a general responsiveness to conspecific songs, because novel swamp sparrow songs never evoked responses from any HVC neurons as strong as those evoked by the strongest adult song type (Fig. 4D). Quantifying the acoustic parameters of each tutor and novel song stimulus revealed no systematic differences in the spectrotemporal structure of these two groups of songs (Fig. $4 E$ ). Therefore, these data indicate that the responsiveness of HVC neurons to individual tutor songs reflects the effects of experience rather than simple acoustic differences between tutor and novel conspecific songs.

Interestingly, although a tutor song evoked the strongest response of any stimulus for the cell shown in Figure 4, not all tutor songs evoked such strong responses. Additional examples of this 

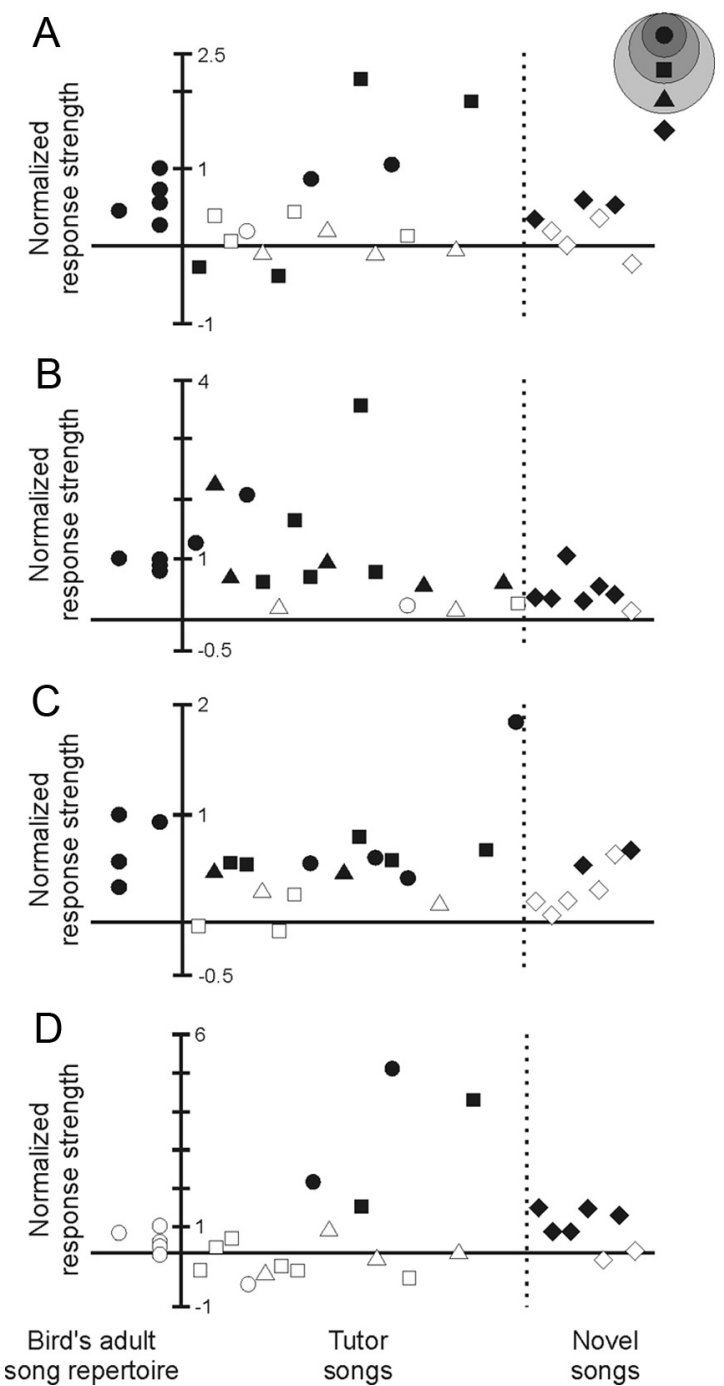

Figure 5. Although the HVC population response is biased toward stronger responses to songs in the adult repertoire, notable exceptions are evident in individual cells. The response of each cell to its strongest adult song type (see text) was used to normalize the responses of that cell to other stimuli. $\boldsymbol{A}-\boldsymbol{C}$, Responses to tutor songs exceeded the response to the strongest adult song type in 14 of 20 cells ( 6 birds), and the identity of those efficacious tutor songs varied across cells and birds (different birds shown in $\boldsymbol{A}-\boldsymbol{C}$; symbols indicate the role of the song in the bird's life history as in Fig. 1E; the dotted vertical lines separate responses to tutor and novel songs; filled symbols, significant response strengths; open symbols, responses that were not significant). $\boldsymbol{D}$, Notably, one HVC neuron expressed no significant response to any song in the adult repertoire, yet that cell responded significantly to other stimuli and most strongly to a tutor song (data from same bird as in $\boldsymbol{A}$ ). Two additional HVC neurons expressed significant decreases in their firing in response to adult songs, yet those cells also expressed strong increases in firing in response to tutor songs (2 birds) (supplemental Fig. 2, available at www.jneurosci.org as supplemental material). Together, these panels represent the full range of responses evident in HVC neurons.

selective responsiveness to only one or a few tutor songs experienced during development are shown in Figure 5. Each cell depicted in this figure responded to only one or a small number of tutor songs more strongly than the strongest adult song type (Fig. $5 A-D)$. Interestingly, this robust responsiveness to certain tutor songs was detected even in the one cell that did not respond to any song in the bird's adult repertoire (Fig. 5D) and in two cells that significantly decreased their activity in response to adult songs (supplemental Fig. 2, available at www.jneurosci.org as supplemental material). Tutor song responses in individual HVC neurons are further quantified in Table 1 , revealing that although
HVC neurons never expressed a significantly stronger response to a novel song than to the strongest adult song type, HVC cells commonly responded more strongly to tutor songs than to the strongest adult song type $(N=1.90 \pm 0.51$ tutor song types per cell exceeded response to strongest adult song type; mean \pm SE; 9 cells; 5 birds). Thus, individual HVC neurons that expressed significant auditory responses to one or more song types in the bird's adult repertoire could also express an even stronger response to a tutor song.

Because HVC neurons can be active in association with both hearing and singing adult song types (Prather et al., 2008), we asked whether auditory responses were limited to those tutor songs that had served as models for songs retained in the bird's adult repertoire. We found, however, that compared with responses evoked by the strongest adult song type, some HVC cells responded significantly more strongly to tutor songs of which only plastic copies were sung ( $d^{\prime}<-0.7 ; N=6$ songs, 4 cells, 2 birds) (Table 1). Intriguingly, auditory responses that were significantly greater than the response to the strongest adult song type were also evoked in two cells by tutor songs that the bird either performed copies of too rarely to be detected in our record of its song development or simply never imitated at all $(N=3$ songs, 2 cells, 2 birds) (Table 1). Thus, HVC neurons could respond more strongly to tutor songs than to any song in the adult repertoire, even when copies of these tutor songs were sung only transiently or possibly not at all.

\section{Strength of response to tutor song is independent of the number of times that a copied song was performed}

Many previous studies suggest that auditory responses of neurons in HVC and other parts of the song system are activated primarily by songs in the bird's adult repertoire (Margoliash, 1986; Doupe and Konishi, 1991; Sutter and Margoliash, 1994; Lewicki, 1996; Volman, 1996; Doupe, 1997; Solis and Doupe, 2000; Sugiyama and Mooney, 2004; Nick and Konishi, 2005; Roy and Mooney, 2007). In that light, one prediction is that responses of swamp sparrow HVC neurons to tutor songs could reflect how frequently the bird sang its copy of that tutor song. To investigate this possibility, we first considered the subset of tutor songs that served as models for song types that the bird performed during crystallized song. As mentioned above, not all adult song types were performed in equal measure (supplemental Fig. $4 A, B$, available at www.jneurosci.org as supplemental material). Some crystallized songs were performed commonly in the adult state (e.g., 124 renditions in the plastic state, 2718 renditions in the crystallized state) (supplemental Fig. 4A, top left, available at www. jneurosci.org as supplemental material), whereas other songs were performed only rarely in the adult crystallized state (e.g., 124 renditions in the plastic state, 1 rendition in the crystallized state) (supplemental Fig. 4A, bottom left, available at www.jneurosci. org as supplemental material). As an initial step in testing the effect of previous performance on the strength of neural representation, we compared responses to commonly performed (adult repertoire) versus rarely performed crystallized song types (as defined above). If the strength of tutor song responses in HVC were related to how frequently a copied song has been sung, then we would expect stronger responses to tutor songs that served as models for commonly performed adult song types. However, we found that tutor songs serving as models for commonly performed adult song types ( $N=3$ tutor songs, 3 cells, 3 birds) and rarely performed adult song types ( $N=5$ tutor songs, 4 cells, 3 birds) were just as likely to evoke responses exceeding that evoked by the strongest adult song type ( $p=0.39$, Mann-Whitney $U$ test $)$. Thus, robust 
responsiveness to a tutor song did not appear to be tightly linked to how frequently the adult sang its copy of that song.

As a different approach to answering this question, we asked whether the strength of tutor song responses recorded in the adult HVC was related to the total number of times the bird had sung a copy of that song in our recorded samples. We considered the set of tutor songs that the bird imitated at any point in its life and compared the strength of neural responses to those tutor songs to the number of times the bird sang a copy of each song. The strength of neural response to a tutor song was unrelated to the number of times that the bird performed that song in the juvenile plastic state (Fig. 6A), the adult crystallized state (Fig. 6B), or in total throughout its lifetime (Fig. 6C,D). Therefore, responsiveness of an HVC neuron to a tutor song does not appear to be influenced by how often the bird had performed a copy of that song throughout development.

\section{HVC neurons respond to acoustically distinct adult and tutor songs}

The responses of individual HVC neurons to multiple song types led us to question whether a given neuron was responding to multiple acoustically distinct songs or to one acoustic sequence that was shared across multiple song types. To explore this issue, we first considered the subset of tutor songs that were copied and maintained in the bird's adult repertoire. Because a tutor song and the bird's copy of that song are typically very similar in their acoustic structures (Fig. 7A-C), a neuron responsive to shared acoustic features should respond comparably to the two songs. However, there was no relationship between the accuracy of a bird's imitation of a particular tutor song and the strength of that bird's neural response to the bird's copy versus the tutor song itself (Fig. 7A-E). Responses to the tutor song corresponding to the strongest adult song type varied widely from -93 to $162 \%$ of the response to the strongest adult song type $(66 \pm 15 \%$; mean \pm SE; $N=14$ cells, 6 birds). Moreover, five cells had no response to the tutor song that served as the model for the strongest adult song type, yet did respond to other acoustically distinct tutor songs (Fig. 7A-D). Finally, the spectrographic cross-correlation (Clark et al., 1987; Nowicki et al., 2002) between the most effective tutor song and the strongest adult song type $(0.37 \pm 0.04)$ was often much less than the correlation between the strongest adult song type and its corresponding model $(0.67 \pm 0.03$; mean $\pm \mathrm{SE} ; p<0.0001$, paired $t$ test; $N=20$ song types). Thus, the acoustic similarity of the strongest adult song type and the tutor song on which it was modeled (Fig. 7C) did not dictate that a neuron would respond similarly to those two stimuli.

To further investigate a possible influence of acoustic similarity in driving responses to multiple songs in individual neurons, we used spectrographic cross-correlation to measure the acoustic similarity among the set of repertoire, tutor, and novel song types that were presented to each cell. Using the strongest adult song type of each neuron as the standard for comparison, we computed the spectrographic similarity between a representative syl- lable of the strongest adult song type and of each song that also evoked a significant auditory response (effective stimuli). We also computed the similarity between the strongest adult song type and the set of songs that did not evoke significant auditory responses (ineffective stimuli), and we tested whether effective stimuli were systematically more like the strongest adult song type of the cell than were ineffective stimuli (Fig. 8A). Across all HVC neurons that significantly increased their activity in response to at least one of the bird's adult song types, there was no difference in the spectrographic similarity between the strongest adult song type and the effective stimuli for that cell $(0.36 \pm 0.02$; mean \pm SE; average cross-correlation score; $N=20$ cells, 6 birds) and between the strongest adult song type and the ineffective stimuli for the same cell $(0.34 \pm 0.02)$ (Fig. $8 A)$. In addition, the acoustic similarity between the strongest adult song type and individual ineffective stimuli exceeded the average similarity between that adult song and individual effective stimuli in $36 \pm 5 \%$ (mean $\pm \mathrm{SE}$ ) of cases. Therefore, the songs that evoked responses in a given neuron were no more acoustically similar to the strongest adult song type than were the songs that did not evoke responses. This result indicates that the collection of songs to which an individual neuron responded were not simply those that shared some acoustic sequence, suggesting that individual HVC neurons can represent multiple acoustically distinct song types.

We also considered that many neurons responded more effectively to a certain tutor song than to the strongest adult song type and that this more effective song might serve as a better standard for comparison. We therefore repeated the above comparisons in each cell, except we used as our standard of comparison the most efficacious stimulus for that cell, regardless of whether it was a part of the bird's adult repertoire or was a tutor song (Fig. $8 B$ ) (no 


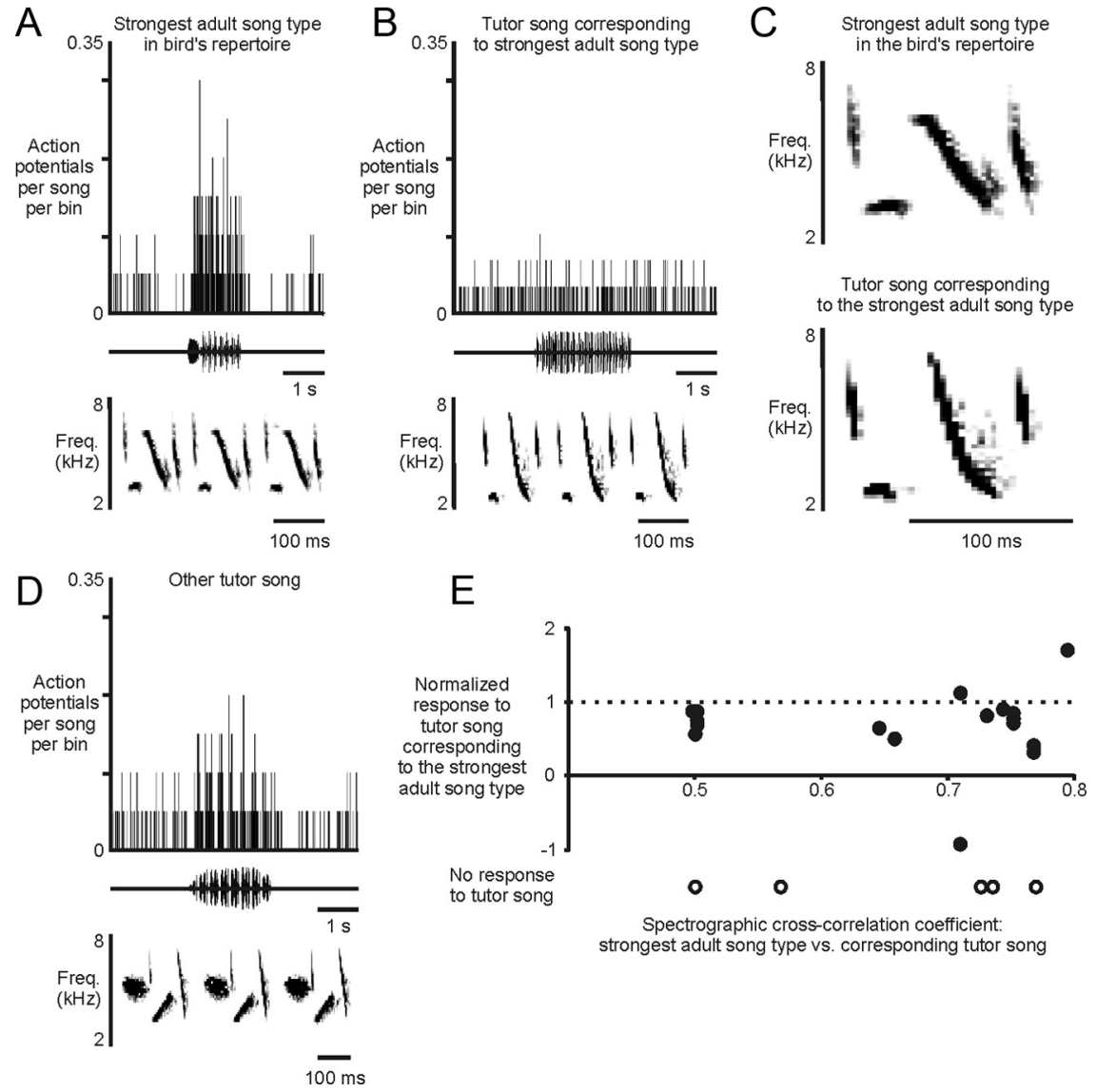

Figure 7. Individual HVC neurons can represent multiple acoustically distinct song types. $A, B$, An individual HVC neuron could respond robustly to its strongest adult song type $(\boldsymbol{A})$ but not at all to the tutor song that served as the model for the bird's performance of that strongest adult song type $(\boldsymbol{B})$. C, Although the strongest adult song type for the cell shown in $\boldsymbol{A}$ and $\boldsymbol{B}$ (top) and the corresponding tutor song (bottom) were similar in their acoustic structure, gross acoustic similarity did not dictate that the same neuron responded to both songs [ 5 cells ( 5 birds) responded to the strongest adult song type but not to the corresponding tutor song]. $\boldsymbol{D}$, Notably, the same cell as in $\boldsymbol{A}$ and $\boldsymbol{B}$ also responded to a tutor song that was acoustically distinct from the strongest adult song type and its corresponding tutor song. $\boldsymbol{E}$, There was no relationship between the spectrographic cross-correlation coefficient indicating the accuracy of a bird's imitation of a particular tutor song and the strength of the response of a neuron to the bird's copy versus the tutor song itself $(p=0.84$; Pearson's correlation; $N=17$ cells, 6 birds; filled symbols, significant responses; open symbols, no significant response). Thus, gross similarity in the acoustic features of two stimuli did not dictate that an individual neuron would respond similarly to those stimuli, indicating that individual HVC neurons can represent multiple acoustically distinct song types.

novel song was ever the most efficacious stimulus). As in the previous comparison, there was no significant difference between that standard of comparison and the set of effective stimuli $(0.33 \pm 0.02)$ and between that standard and the set of ineffective stimuli $(0.32 \pm 0.02)$ (Fig. $8 B$ ). Furthermore, the acoustic similarity between the standard of comparison and individual ineffective stimuli exceeded the average similarity between that standard and individual effective stimuli in $43 \pm 5 \%$ of cases. These results lend additional support to the idea that the responses of individual HVC neurons to multiple adult and tutor song types cannot be explained by acoustic similarity between the syllables that define each swamp sparrow song.

Finally, we considered that multiple song types could share an acoustic sequence that spanned only a subset of the notes in their respective song syllables. Because such a subsyllabic structure could have been obscured in our spectrographic correlations of full syllables, we broke each representative syllable into its constituent notes and compared song structures at a per-note resolution (Fig. 8C-F). Computing the similarity of each note in the syllable of our standard of comparison versus each note in the syllable of each effective and ineffective stimulus, we again found that there was no systematic difference between the standard and the effective stimuli and between the standard and the ineffective stimuli (Fig. 8C-F). Together, these three analyses of acoustic structure, considering the same data at both a per-syllable and a per-note resolution, failed to detect any acoustic differences that predicted the observed differences in auditory response. We failed to detect differences regardless of whether these comparisons were performed with or without time warping (see Materials and Methods). Furthermore, even though the tonality of swamp sparrow song would tend to make the crosscorrelation method more sensitive to acoustic differences than for other less tonal species (e.g., zebra finches), no such differences emerged. These analyses indicate that the responses of individual HVC neurons to multiple songs are not explained by simple acoustic similarity among the effective stimuli. Thus, it appears that, in addition to responding to songs that are part of the bird's adult vocal repertoire, individual neurons in the adult swamp sparrow HVC also can respond selectively to acoustically distinct tutor songs.

\section{Discussion}

By documenting the auditory experience and vocal development of individual swamp sparrows, we found that HVC neurons contain a lasting record of experience associated with exuberant juvenile learning. Individual neurons responded to song types in the adult repertoire and to certain tutor songs, and tutor songs that drove responses were not simply those that were acoustically similar to song types in the bird's adult repertoire. Furthermore, the strength of response to tutor songs was unrelated to the number of times the bird sang copies of those songs in juvenile or adult life. Consequently, the same neurons that respond to song types in the bird's adult repertoire appear to retain a lasting record of experience associated with transiently performed juvenile behaviors.

Our finding that some tutor songs can evoke strong responses in the adult swamp sparrow HVC contrasts with previous studies. A study in white-crowned sparrows revealed HVC neurons that were strongly responsive to the bird's adult song and the tutor song on which it was modeled, but those cells were rare, and most neurons responded most strongly to the bird's adult song (Margoliash, 1986). By presenting an adult swamp sparrow the majority of its tutor songs, we found that most HVC neurons responded more strongly to at least one of those songs than to any song in the bird's adult repertoire. This more common representation of tutor song experience in swamp sparrows may reflect the fact that our testing used nearly all possible early life experiences, or it may be related to the ability of the adult swamp 


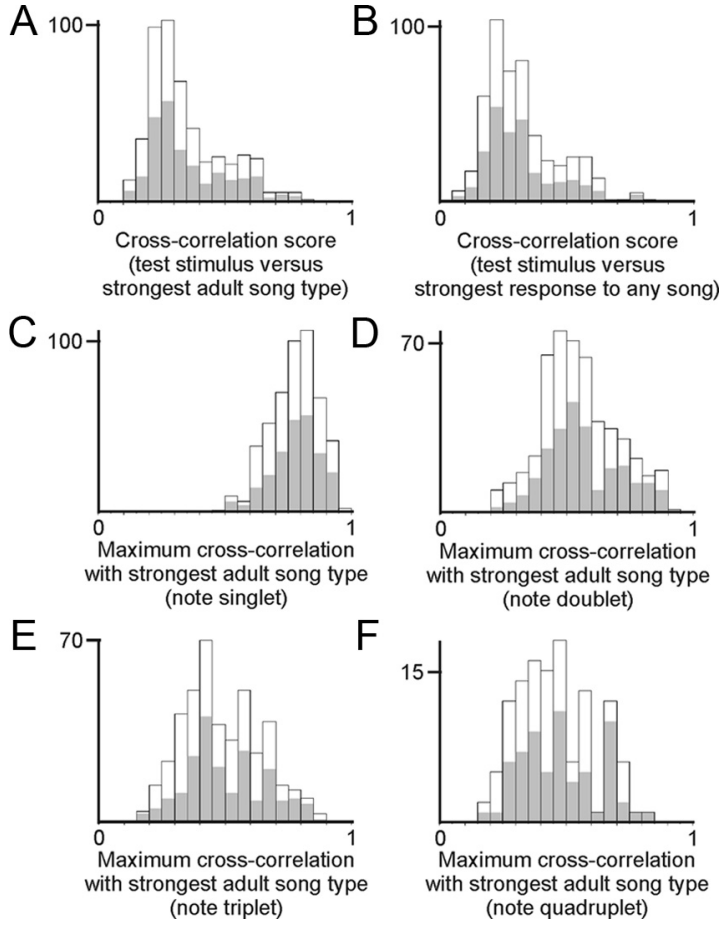

Figure 8. Responses of individual neurons to multiple song types are not explained by acoustic similarity on the scale of full syllables or individual notes. Spectrographic cross-correlation (Clark etal., 1987; Nowicki et al., 2002) was used to compare the acoustic structure of a representative syllable of each adult, tutor and novel song versus either the syllable of the strongest adult song type in each cell $(\boldsymbol{A})$, or the syllable of the song type that evoked the strongest response in each cell, regardless of whether that song was part of the birds' adult repertoire $(\boldsymbol{B})$. In each case, there was no difference between the cross-correlation scores of stimuli that did evoke a significant response (shaded regions in each bar) and the stimuli that did not evoke a significant response (open regions in each bar; $A, p=$ $0.42 ; \boldsymbol{B}, p=0.67$, Mann-Whitney $U$ test; $N=20$ cells, 6 birds). $\mathbf{C}-\boldsymbol{F}$, Because multiple song types could share an acoustic sequence that spanned only a subset of the song syllable, we also compared song structures at a per-note resolution. Comparing individual notes $(\boldsymbol{C})$, two-note sequences $(\boldsymbol{D})$, three-note sequences $(\boldsymbol{E})$, and four-note sequences $(\boldsymbol{F})$, there was no difference between the crosscorrelation scores of the stimuli that did evoke a significant response (shaded regions in each bar) versus the stimuli that did not evoke a significant response (open regions in each bar; $\boldsymbol{C}, p=0.28 ; \boldsymbol{D}$, $p=0.20 ; \boldsymbol{E}, p=0.61 ; \boldsymbol{F}, p=0.46$, Mann-Whitney $U$ test; $N=20$ cells, 6 birds). Together, these analyses of acoustic structure, considering the same data at both a per-syllable and a per-note resolution, reveal that individual HVC neurons can represent multiple acoustically distinct song types.

sparrow to copy and maintain multiple song types in its repertoire. Our results also contrast with previous studies of zebra finches that have examined the representation of early auditory and vocal experience in the song system. Although song system neurons in juvenile finches respond to the tutor song and the juvenile's imitation of that song, song system neurons in the adult respond most strongly to the bird's crystallized song, suggesting that the record of early experience is lost or overwritten during development (Volman, 1996; Doupe and Solis, 1997; Solis and Doupe, 1997, 1999; Sugiyama and Mooney, 2004; Nick and Konishi, 2005). In notable contrast to swamp sparrows, zebra finch song development involves serial revision of the juvenile's imitation of a single tutor, resulting in a learning trajectory in which juvenile performances are acoustically similar to the adult song (Tchernichovski et al., 2001). This developmental trajectory may obscure any lasting effects of juvenile experience in adult zebra finches, even in birds learning sequentially from two different tutors (Sugiyama and Mooney, 2004). In swamp sparrows, the production of juvenile songs acoustically distinct from those maintained in the adult repertoire provides a natural means of disambiguating juvenile and adult experience, revealing a persistent effect of juvenile experience in the adult brain.

Several factors could potentially contribute to the tutorevoked responses we observed in HVC, including auditory experience of the tutor song, and vocal rehearsal, and the associated sensory feedback. Nonetheless, two observations suggest responses to tutor songs in the adult may be linked more strongly to auditory experience of the tutor song than to these other factors. First, some tutor songs evoked responses from an HVC neuron that exceeded the response of the cell to song types in the adult repertoire. Notably, for a given neuron, these effective tutor songs did not necessarily include the model for the strongest adult song type, nor were they acoustically similar to that song type. Second, robust responses to a tutor song were not correlated with the amount a bird performed its copy of that song in juvenile or adult life. In a few instances, tutor songs of which copies were sung only rarely during development, or never in our records, could nonetheless evoke a response from a neuron exceeding its strongest response to any song in the adult repertoire. Together, these observations suggest that HVC can encode a lasting effect of auditory experience of a tutor song or some form of sensorimotor experience not simply dependent on how much a song was performed.

The response of adult HVC neurons to tutor songs of which copies were sung only transiently indicates a lasting effect of early experience on HVC circuitry. One possibility is that, during plastic song, different HVC neurons develop selectivity for different songs, with the neuronal population representing the bird's complete repertoire. During crystallization, the representation of song types maintained in the adult repertoire could expand to subsume neurons originally associated with eliminated song types, without totally erasing this earlier representation. Such an expansion is evident in the increased cortical representation of intact structures after selective alteration or removal of somatosensory (Kalaska and Pomeranz, 1979), vibrissal (Waite and Taylor, 1978), or visual inputs (Hubel and Wiesel, 1965). For example, in cats, surgically closing one eye during a juvenile sensitive period can result in an expanded cortical representation of the open eye (Hubel and Wiesel, 1965), and in mice such experience-dependent changes are associated with increases in the number of dendritic spines on cortical neurons (Hofer et al., 2009). Although restoration of binocular vision can restore normal cortical patterns of ocular dominance, many of the spines formed during monocular deprivation remain, and subsequent occlusion of the same eye results in much faster expression of the same changes in ocular dominance, suggesting a persistent effect of abnormal visual experience (Hofer et al., 2009). In barn owls, abnormal visual experience during a juvenile sensitive period triggers adaptive expansion of synaptic projections encoding auditory space in the midbrain (Feldman and Knudsen, 1997), and those projections persist even after normal vision is restored (Linkenhoker et al., 2005). In both of these systems, persistent synapses are thought to facilitate adaptive plasticity when the abnormal form of early experience is encountered again after closure of the sensitive period (Knudsen, 1998; Hofer et al., 2009). Our findings provide evidence that multiple types of experience normally encountered during juvenile life can also persist in the adult brain.

An important goal will be to determine how widely within the auditory or sensorimotor network these lasting effects of early experience are encoded. In support of the idea that the selective representations of certain tutor songs emerge within HVC itself, intracellular recordings of HVC neurons in anesthetized adult songbirds, including swamp sparrows (Mooney et al., 2001), reveal that even though synaptic drive onto individual HVC neurons can be activated by many songs, local inhibition sharpens 
the selectivity of some HVC neurons so that they generate action potentials almost exclusively to the bird's adult song (Mooney, 2000; Rosen and Mooney, 2006). Alternatively, selective tutor song representation may originate in areas presynaptic to HVC (Bolhuis et al., 2000; Coleman and Mooney, 2004; Terpstra et al., 2004; Bauer et al., 2008). These alternatives could be distinguished through a comprehensive analysis of these various sites, and by reversibly inactivating HVC to assess the selectivity of extrinsic inputs onto HVC neurons (Rosen and Mooney, 2003, 2006).

The functional implications of auditory responses in HVC to transiently performed songs and to songs that persist into adulthood remain unknown. HVC has been implicated in song perception (Brenowitz, 1991; Gentner et al., 2000; Prather et al., 2009), raising the possibility that juvenile vocal overproduction leads to a persistently expanded song representation in HVC, which in turn enhances adult perception of conspecific songs. In this light, it is noteworthy that bilingual children who subsequently speak only one language as adults nonetheless retain an enhanced ability to distinguish speech sounds of the abandoned language (Tees and Werker, 1984). Persistent representation of juvenile song experience may act similarly to enhance a swamp sparrow's ability to recognize different song types, even those not in its adult repertoire. Just as human recognition of speech is enhanced through familiarity with those and other similar sounds (Streeter, 1976; Iverson et al., 2003), some data suggest songbirds can also more easily discriminate familiar songs (Cynx and Nottebohm, 1992; Weary and Krebs, 1992). A previous study of freely behaving swamp sparrows showed that the auditory responses of some HVC neurons are linked to song perception (Prather et al., 2009). Perhaps the persistent adult representation of songs experienced in the bird's native population provides a perceptual referent against which songs of other birds can be compared. Swamp sparrows discriminate their local song dialect from songs of more distant populations (Balaban, 1988a,b) and do so in part by categorically perceiving subtle acoustic differences (Nelson and Marler, 1989; Prather et al., 2009). Swamp sparrows also discriminate among differing levels of "vocal performance" of song, a measure of how well an individual sings acoustic features that are physically challenging to produce (Ballentine et al., 2004; DuBois et al., 2009). These discriminations come into play in both male territorial aggression and female mate choice, suggesting an important functional role for a broader representation of conspecific songs in the songbird brain. This role could be facilitated by the persistent representation in HVC of copied tutor songs, even when these copies are not maintained in the adult repertoire.

\section{References}

Balaban E (1988a) Cultural and genetic variation in swamp sparrows (Melospiza georgiana). 1. Song variation, genetic variation, and their relationship. Behaviour 105:250-291.

Balaban E (1988b) Cultural and genetic variation in swamp sparrows (Melospiza georgiana). 2. Behavioral salience of geographic song variants. Behaviour 105:292-322.

Ballentine B, Hyman J, Nowicki S (2004) Vocal performance influences female response to male bird song: an experimental test. Behav Ecol $15: 163-168$.

Bauer EE, Coleman MJ, Roberts TF, Roy A, Prather JF, Mooney R (2008) A synaptic basis for auditory-vocal integration in the songbird. J Neurosci 28:1509-1522.

Bolhuis JJ, Gahr M (2006) Neural mechanisms of birdsong memory. Nat Rev Neurosci 7:347-357.

Bolhuis JJ, Zijlstra GG, den Boer-Visser AM, Van Der Zee EA (2000) Local- ized neuronal activation in the zebra finch brain is related to the strength of song learning. Proc Natl Acad Sci U S A 97:2282-2285.

Brenowitz EA (1991) Altered perception of species-specific song by female birds after lesions of a forebrain nucleus. Science 251:303-305.

Catchpole CK, Slater PJB (1995) Birdsong: biological themes and variations. New York: Cambridge UP.

Clark CW, Marler P, Beeman K (1987) Quantitative analysis of animal vocal phonology: an application to swamp sparrow song. Ethology 76:101-115.

Coleman MJ, Mooney R (2004) Synaptic transformations underlying highly selective auditory representations of learned birdsong. J Neurosci 24:9251-9265.

Cynx J, Nottebohm F (1992) Role of gender, season, and familiarity in discrimination of conspecific song by zebra finches (Taeniopygia guttata). Proc Natl Acad Sci U S A 89:1368-1371.

Doupe AJ (1997) Song- and order-selective neurons in the songbird anterior forebrain and their emergence during vocal development. J Neurosci 17:1147-1167.

Doupe AJ, Konishi M (1991) Song-selective auditory circuits in the vocal control system of the zebra finch. Proc Natl Acad Sci U S A 88: $11339-11343$.

Doupe AJ, Solis MM (1997) Song- and order-selective neurons develop in the songbird anterior forebrain during vocal learning. J Neurobiol 33:694-709.

DuBois AL, Nowicki S, Searcy WA (2009) Swamp sparrows modulate vocal performance in an aggressive context. Biol Lett 5:163-165.

Feldman DE, Knudsen EI (1997) An anatomical basis for visual calibration of the auditory space map in the barn owl's midbrain. J Neurosci 17:6820-6837.

Fox K (1992) A critical period for experience-dependent synaptic plasticity in rat barrel cortex. J Neurosci 12:1826-1838.

Geberzahn N, Hultsch H, Todt D (2002) Latent song type memories are accessible through auditory stimulation in a hand-reared songbird. Anim Behav 64:783-790.

Gentner TQ, Hulse SH, Bentley GE, Ball GF (2000) Individual vocal recognition and the effect of partial lesions to HVc on discrimination, learning, and categorization of conspecific song in adult songbirds. J Neurobiol 42:117-133.

Green D, Swets J (1966) Signal detection theory and psychophysics. New York: Wiley.

Hahnloser RH, Kozhevnikov AA, Fee MS (2002) An ultra-sparse code underlies the generation of neural sequences in a songbird. Nature 419:65-70.

Hofer SB, Mrsic-Flogel TD, Bonhoeffer T, Hübener M (2009) Experience leaves a lasting structural trace in cortical circuits. Nature 457:313-317.

Hubel DH, Wiesel TN (1965) Binocular interaction in striate cortex of kittens reared with artificial squint. J Neurophysiol 28:1041-1059.

Iverson P, Kuhl PK, Akahane-Yamada R, Diesch E, Tohkura Y, Kettermann A, Siebert C (2003) A perceptual interference account of acquisition difficulties for non-native phonemes. Cognition 87:B47-B57.

Jarvis ED, Güntürkün O, Bruce L, Csillag A, Karten H, Kuenzel W, Medina L, Paxinos G, Perkel DJ, Shimizu T, Striedter G, Wild JM, Ball GF, DugasFord J, Durand SE, Hough GE, Husband S, Kubikova L, Lee DW, Mello CV, et al. (2005) Avian brains and a new understanding of vertebrate brain evolution. Nat Rev Neurosci 6:151-159.

Kalaska J, Pomeranz B (1979) Chronic paw denervation causes an agedependent appearance of novel responses from forearm in "paw cortex" of kittens and adult cats. J Neurophysiol 42:618-633.

Knudsen EI (1998) Capacity for plasticity in the adult owl auditory system expanded by juvenile experience. Science 279:1531-1533.

Knudsen EI (2004) Sensitive periods in the development of the brain and behavior. J Cogn Neurosci 16:1412-1425.

Lachlan RF, Verhagen L, Peters S, Cate CT (2010) Are there speciesuniversal categories in bird song phonology and syntax? A comparative study of chaffinches (Fringilla coelebs), zebra finches (Taenopygia guttata), and swamp sparrows (Melospiza georgiana). J Comp Psychol 124:92-108.

Lewicki MS (1996) Intracellular characterization of song-specific neurons in the zebra finch auditory forebrain. J Neurosci 16:5855-5863.

Lewicki MS, Konishi M (1995) Mechanisms underlying the sensitivity of songbird forebrain neurons to temporal order. Proc Natl Acad Sci U S A 92:5582-5586.

Linkenhoker BA, von der Ohe CG, Knudsen EI (2005) Anatomical traces of 
juvenile learning in the auditory system of adult barn owls. Nat Neurosci 8:93-98.

Locke J (1993) The child's path to spoken language. Cambridge, MA: Harvard UP.

Margoliash D (1986) Preference for autogenous song by auditory neurons in a song system nucleus of the white-crowned sparrow. J Neurosci 6:1643-1661.

Margoliash D, Fortune ES (1992) Temporal and harmonic combinationsensitive neurons in the zebra finch's HVc. J Neurosci 12:4309-4326.

Margoliash D, Konishi M (1985) Auditory representation of autogenous song in the song system of white-crowned sparrows. Proc Natl Acad Sci U S A 82:5997-6000.

Marler P (1956) Behavior of the chaffinch. Behav Suppl 6:1-186.

Marler P (1991) Song-learning behavior: the interface with neuroethology. Trends Neurosci 14:199-206.

Marler P, Peters S (1981) Sparrows learn adult song and more from memory. Science 213:780-782.

Marler P, Peters S (1982a) Developmental overproduction and selective attrition: new processes in the epigenesis of birdsong. Dev Psychobiol 15:369-378.

Marler P, Peters S (1982b) Long-term storage of learned birdsongs prior to production. Anim Behav 30:479-482.

Marler P, Peters S (1982c) Structural changes in song ontogeny in the swamp sparrow Melospiza georgiana. Auk 99:446-458.

Marler P, Peters S (1988) Sensitive periods for song acquisition from tape recordings and live tutors in the swamp sparrow, Melospiza georgiana. Ethology 77:76-84.

McCasland JS, Konishi M (1981) Interaction between auditory and motor activities in an avian song control nucleus. Proc Natl Acad Sci U S A 78:7815-7819.

Mooney R (2000) Different subthreshold mechanisms underlie song selectivity in identified HVc neurons of the zebra finch. J Neurosci 20:5420-5436.

Mooney R, Hoese W, Nowicki S (2001) Auditory representation of the vocal repertoire in a songbird with multiple song types. Proc Natl Acad Sci U S A 98:12778-12783.

Nelson DA, Marler P (1989) Categorical perception of a natural stimulus continuum: birdsong. Science 244:976-978.

Nick TA, Konishi M (2005) Neural song preference during vocal learning in the zebra finch depends on age and state. J Neurobiol 62:231-242.

Nottebohm F, Stokes TM, Leonard CM (1976) Central control of song in the canary, Serinus canarius. J Comp Neurol 165:457-486.

Nowicki S, Searcy WA, Peters S (2002) Brain development, song learning and mate choice in birds: a review and experimental test of the "nutritional stress hypothesis." J Comp Physiol A Neuroethol Sens Neural Behav Physiol 188:1003-1014.

Prather JF, Peters S, Nowicki S, Mooney R (2008) Precise auditory-vocal mirroring in neurons for learned vocal communication. Nature 451:305-310.
Prather JF, Nowicki S, Anderson RC, Peters S, Mooney R (2009) Neural correlates of categorical perception in learned vocal communication. Nat Neurosci 12:221-228.

Quiroga RQ, Nadasdy Z, Ben-Shaul Y (2004) Unsupervised spike detection and sorting with wavelets and superparamagnetic clustering. Neural Comput 16:1661-1687.

Rosen MJ, Mooney R (2003) Inhibitory and excitatory mechanisms underlying auditory responses to learned vocalizations in the songbird nucleus HVC. Neuron 39:177-194.

Rosen MJ, Mooney R (2006) Synaptic interactions underlying songselectivity in the avian nucleus HVC revealed by dual intracellular recordings. J Neurophysiol 95:1158-1175.

Roy A, Mooney R (2007) Auditory plasticity in a basal ganglia-forebrain pathway during decrystallization of adult birdsong. J Neurosci 27: 6374-6387.

Solis MM, Doupe AJ (1997) Anterior forebrain neurons develop selectivity by an intermediate stage of birdsong learning. J Neurosci 17:6447-6462.

Solis MM, Doupe AJ (1999) Contributions of tutor and bird's own song experience to neural selectivity in the songbird anterior forebrain. J Neurosci 19:4559-4584.

Solis MM, Doupe AJ (2000) Compromised neural selectivity for song in birds with impaired sensorimotor learning. Neuron 25:109-121.

Streeter LA (1976) Language perception of 2-month-old infants shows effects of both innate mechanisms and experience. Nature 259:39-41.

Sugiyama Y-Y, Mooney R (2004) Sequential learning from multiple tutors and serial retuning of neurons in a brain area important to birdsong learning. J Neurophysiol 92:2771-2788.

Sutter ML, Margoliash D (1994) Global synchronous response to autogenous song in zebra finch HVc. J Neurophysiol 72:2105-2123.

Tchernichovski O, Nottebohm F, Ho CE, Pesaran B, Mitra PP (2000) A procedure for an automated measurement of song similarity. Anim Behav 59:1167-1176.

Tchernichovski O, Mitra PP, Lints T, Nottebohm F (2001) Dynamics of the vocal imitation process: how a zebra finch learns its song. Science 291:2564-2569.

Tees RC, Werker JF (1984) Perceptual flexibility: maintenance or recovery of the ability to discriminate non-native speech sounds. Can J Psychol 38:579-590.

Terpstra NJ, Bolhuis JJ, den Boer-Visser AM (2004) An analysis of the neural representation of birdsong memory. J Neurosci 24:4971-4977.

Volman SF (1996) Quantitative assessment of song-selectivity in the zebra finch "high vocal center." J Comp Physiol A Neuroethol Sens Neural Behav Physiol 178:849-862.

Waite PM, Taylor PK (1978) Removal of whiskers in young rats causes functional changes in cerebral cortex. Nature 274:600-602.

Weary DM, Krebs JR (1992) Great tits classify songs by individual voice characteristics. Anim Behav 43:283-287.

Yu AC, Margoliash D (1996) Temporal hierarchical control of singing in birds. Science 273:1871-1875. 